\title{
RISK AND RETURN MANAGEMENT OF SHARIA STOCKS IN JAKARTA ISLAMIC INDEX FOR THE PERIOD OF 2009 - 2019 USING MARKOWITZ PORTOFOLIO MANAGEMENT
}

\author{
Widhiyo Sudiyono, ST, MAB \\ Faculty of Economics and Business, University of Muhammadiyah Malang \\ Email :widhiyo@umm.ac.id
}

\begin{abstract}
:
To reduce risk in investment and at the same time optimize the returns, it is necessary to establish a series of stocks that have high returns, as well as to select a series of stock with negative variance to reduce the risk. In this research, an efficient frontier approach by Harry Markowitz will be applied to JII shares during the period 2009 - 2019 so that a portfolio with a low risk and optimal return can be formed to reduce risk and optimize return.
\end{abstract}

Keywords :

Efficient Frontier, Sharia Stock, Markowitz Portfolio Theory JII

\section{Preface}

The annual Indonesia's inflation rate quickened to $2.98 \%$ in February 2020 from $2.68 \%$ in January 2020. This rate is above the market expectations of $2.86 \%$. The february 2020 inflation rate was the highest inflation rate since last November. It is driven to surge by prices of food, drinks, tobacco $(6.02 \%$ vs $4.31 \%)$, especially due to shortages of garlic and also indicating the recent increase of tax rate on tobacco products imposed by Indonesian government. Meanwhile, prices diminished for housing \& utilities $(1.38 \%$ vs $1.60 \%)$; personal care \& other services (4.64\% vs $4.71 \%)$; recreation, sport \& culture (1.73\% vs $1.80 \%)$; furnishings $(2.71 \%$ vs $2.81 \%$ ); education $(3.77 \%$ vs $3.81 \%)$, food services \& restaurant $(3.79 \%$ vs $3.97 \%)$. Also, some costs slightly dropped for transport (-0.31\% vs $0.05 \%)$ and information, communication \& financial services $(-0.06 \%$ vs $-0.11 \%)$. Additionally, the annual core inflation slightly fell to $2.76 \%$ from $2.88 \%$, the lowest since June 2018, below the forecasts of 2.85 percent. On a monthly basis, consumer prices surged $0.28 \%$ in February, the least since November 2019, after a $0.39 \%$ gain in the preceding month.[ https://tradingeconomics.com/indonesia/inflation-cpi].

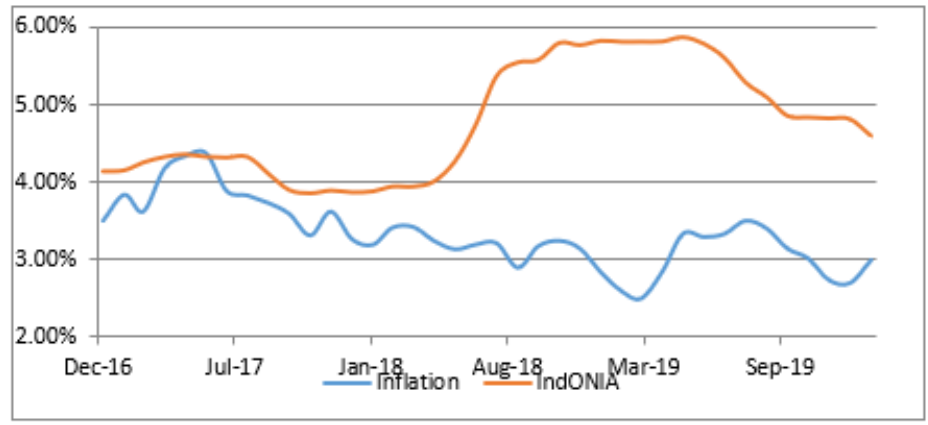

Furthermore, by comparing the Indonesian inflation rate for the last three years and the Indonesia overnight index average(Indonia), a benchmark rate fo money market released by the central bank of Indonesia for the respective period, there are very limited differences to gain 
International Journal of Economics, Business, and Accounting Research (IJEBAR)

Peer Reviewed - International Journal

Vol-5, Issue-1, 2021 (IJEBAR)

E-ISSN: 2614-1280 P-ISSN 2622-4771

https://jurnal.stie-aas.ac.id/index.php/IJEBAR

from investing by saving money in the bank. Thus, a better return of investment needs to be established to pursue return higher than both inflation and indonia rate. One of investments that provide a higher return is stock investing. However, investing in the stock market is a risky means of investment. Therefore, we need to manage the risk and the return to optimize the investment by Markowtiz portfolio management. The negative covariance between pairs of stocks can be used to reduce stocks market volatility and risk.

\section{The formulation of the problems}

The problem that will be discussed in this final project is

1. How to calculate returns, standard deviations and risks of individual sharia stock investments included in the Jakarta Islamic Index(JII)

2. How to choose stocks that have a better investment return than the JCI index to be eligible for inclusion in the portfolio.

3. How to implement the Markowitz Modern Portfolio theory on leading stocks by utilizing the covariance of a combination of shares to reduce risk

\section{Purpose}

The objectives to be achieved in the implementation of this research are

1. To implement the Markowitz Modern Portfolio theory in Sharia Stock which is included in Jakarta Islamic Index

2. To make investment alternatives with various investment return and risk options

\section{Limitation of Problems}

Limitation problems in this research are:

1. The stock price data used is the stock price data listed on the Jakarta Islamic Index(JII).

2. The duration of observation in this final project is 10 years, starting in January 2009 to December 2019

3. Shares that will be combined to form a portfolio are only stocks - stocks that have a higher return than the JCI return

\section{Review Of Literature}

\section{Stocks}

Stocks are one of the most widely recognized financial market instruments by the general public. To get some funding, issuing shares is one of the ways that can be taken by a company. Meanwhile, for investors, stocks are a very attractive investment instrument because they can provide a very satisfactory level of profit.

In addition, shares can also be defined as a sign of capital participation by individual investors or business entity investors in a company or limited liability company. By including this capital, the investor has a claim on company income and company assets, and is also entitled to attend the RUPS (General Meeting of Shareholders).

\section{Types of Profits from Stocks Market}

There are two kinds of profits that an investor can obtain by investing in the stock market : 


\section{Dividend}

Dividends are a form of profit-sharing provided by the company and the profits come from profits generated by the company. Paying out dividends must obtain approval from shareholders at the General Meeting of Shareholders (GMS). If an investor wants to get a dividend, then the investor must own or hold the shares for a sufficiently long period of time, which is in the period in which the investor is recognized as a shareholder entitled to receive a dividend.

There are two types of dividends distributed by companies. First, dividends can be in the form of cash, meaning that each shareholder is given cash dividends in a certain amount of rupiah per share held. Secondly, dividends can also be in the form of stock dividends. In the distribution of stock dividends, investors will be given a number of shares based on the number of shares they have in accordance with the ratio determined at the GMS (General Meeting of Shareholders).

\section{Capital gain}

Capital Gain can be obtained by investors from the difference between the purchase price and the selling price of shares. Capital gains are obtained from buying and selling shares in the secondary market. The following is a simple illustration of how an investor can obtain capital gains from the purchase and sale of shares, for example an Investor purchases IDR 500,000 of shares from PT Apel Berseri Tbk at a price of IDR 5,000 per share of 100 shares on February 3, 2020. Then The investor kept PT Apel Berseri Tbk shares for one month and sold all of the shares on March 3, 2020 according to a market price of $\mathrm{Rp} \mathrm{550,000} \mathrm{at} \mathrm{a} \mathrm{price} \mathrm{of} \mathrm{Rp} \mathrm{5,500} \mathrm{per}$ share of 100 shares. From the process of buying and selling these shares, investors get a profit of $\mathrm{Rp} \mathrm{50,000} \mathrm{or} \mathrm{Rp.} 500$ per share in a period of one month. So it can be concluded that the investor gets a capital gain of 10 percent in a month.

\section{Type of risks in stock investment}

Stock investment has several kinds of risks, including:

\section{Capital Loss}

Capital loss is the opposite of capital gain. for example an Investor purchases IDR 500,000 shares from PT Apel Berseri Tbk at a price of IDR 5,000 per share as many as 100 shares on February 3, 2020. Then the investor keeps PT Apel Berseri Tbk shares for one month and sells all of these shares on March 3, 2020 according to a market price of Rp 450,000 at a price of Rp 4,500 per share of 100 shares. From the process of buying and selling these shares, the investor gets a loss of Rp 50,000 or Rp. 500 per share in a period of one month. So it can be concluded that the investor gained capital loss of 10 percent in a month.

\section{Liquidation Risk}

In addition to the risk of capital loss, the company's business whose shares are owned by investors, is declared bankrupt by the Court, or it can also be dissolved by the majority shareholder. In this case, claim rights from shareholder investors will get the last priority after all company obligations can be paid, usually obtained from the sale of company assets. If there is still left over from the results of the company's obligations, then the remainder can be distributed proportionally to all investors of the shareholders. On the other hand, if there is no remainder 
after all company obligations have been paid, the shareholders will not get the results of the liquidation of the company. Thus, this condition is the biggest risk form of stock investment. Therefore, a stock investor must keep abreast of developments in the company's business in which he invests funds.

However, if there is no remaining of the company's wealth, shareholders will not get any results of the liquidation. This condition is the heaviest risk of shareholders. For this reason, a shareholder is required to continuously follow the company's news from time to time.

\section{Sharia Stock}

The criteria for selecting sharia shares are based on Bapepam \& LK Regulation No. II.K.1 concerning Criteria and Issuance of Sharia Securities List, article 1.b.7. The regulation states that securities in the form of shares, including Islamic Rights and Sharia Warrants, issued by Issuers or Public Companies that do not state that business activities and ways of managing their business are conducted based on sharia principles, as long as the Issuers or Public Companies:

A. Not conducting business activities as referred to in number 1 letter $b$ Rule Number IX.A.13, namely:

Business activities that are in conflict with Islamic principles including :

1) Gambling and games that is classified as gambling;

2) Sharia-restricted trading includes:

a) trade that is not accompanied by the delivery of goods / services; and

b) trade with fake offers / requests;

3) Usurious financial services, including:

a) interest-based banks;

b) and interest-based finance companies;

4) Buying and selling risks that contain elements of uncertainty (gharar) and / or gambling (maisir), including conventional insurance;

5) Producing, distributing, trading and / or providing, among others:

a) illicit goods or services (illicit li-dzatihi);

b) illicit goods or services not because of their substance (haram li-ghairihi) stipulated by DSN-MUI; and / or

6) Conduct transactions containing elements of bribery (risywah)

B. Comply the financial ratios as follows

1) Total interest-based debt compared to total equity of not more than $82 \%$ (eighty-two percent);

2) Total interest income and other non-halal income compared to total business income (revenue) and other income not more than $10 \%$ (ten percent)

\section{Sharia Stock in Jakarta Islamic Index(JII)}

The Jakarta Islamic Index (JII) is a sharia-based stock index which was first launched on the Indonesian stock exchange on July 3, 2000. There are 30 of the most liquid sharia shares included in JII shares. Just like ISSI, a review of Shariah shares that are JII constituents is conducted twice a year, in May and November, following the OJK's DES review schedule. 
IDX determines and selects sharia shares which are the constituents of JII. The liquidity criteria used in selecting 30 Sharia shares that constitute the JII constituents are as follows:

1. Sharia shares included in the constituents of the Indonesian Sharia Stock Index (ISSI) have been recorded for the past 6 months

2. 60 stocks are chosen based on the highest average market capitalization in the last 1 year

3. Of the 60 shares, 30 shares were then chosen based on the average daily transaction value on the highest regular market

4. The remaining 30 shares are selected shares.

\section{Relevant Statistical Theory}

Average / arithmetic mean or average

If there are $n$ values, where each value is denoted as ai, where $i=1,2, \ldots, n$, then the arithmatic mean is the sum of all values from $\mathrm{a}_{1}$ to $\mathrm{a}_{\mathrm{n}}$ and then divided by $\mathrm{n}$.

$A M=\frac{1}{n} \sum_{i=1}^{n} a i$ where $\mathrm{n}$ is the number of data and $\mathrm{a}$ is the value of the data.

\section{Average or expected value}

If two coins are tossed 16 times and $X$ denotes the number of head appearing on each toss, then the possible value of $\mathrm{X}$ is 0.1 and 2. Suppose that the experiment produced no head 4 times, one head 7 times and two head 5 times. Then the average number of heads that appear each toss of two coins is

$$
\frac{(0)(4)+(1)(7)+(2)(5)}{16}=1,06
$$

This is an average value and it is not necessary to state a result that might have appeared for the experiment [WAL95].

Let $\mathrm{X}$ be a random variable with a probability distribution $\mathrm{f}(\mathrm{x})$. The expected value or average of $\mathrm{X}$

$$
\begin{aligned}
& \mu=E(X)=\sum x f(x) \text { if } X \text { is dicrete } \\
& \text { and } \\
& \mu=E(X)=\int_{-\infty}^{\infty} x f(x) d x \text { if } X \text { is continous[WAL95]. }
\end{aligned}
$$

\section{Variance}

The average or expected value of a random variable $\mathrm{X}$ only describes the location of the distribution center, but does not provide sufficient information about the form of distribution. Diversity of distribution needs to be characterized. The measure of diversity of a random variable $\mathrm{X}$ is obtained from $g(X)=(X-\mu)^{2}$. In statistics, it is named the variance of the random variable $X$ or the variance distributed $X$ or with the symbol $\sigma_{x}^{2}$ or only $\sigma^{2}$ if the intended random variable is clear [WAL95].

Let $\mathrm{X}$ be a random variable with a probability $f(x)$ and averages distribution $\mu$.. Variance $\mathrm{X}$ is $\sigma^{2}=E\left[(X-\mu)^{2}\right]=\sum_{x}(x-\mu)^{2} f(x)$ if $\mathrm{X}$ is discrete

and 
International Journal of Economics, Business, and Accounting Research (IJEBAR)

Peer Reviewed - International Journal

Vol-5, Issue-1, 2021 (IJEBAR)

E-ISSN: 2614-1280 P-ISSN 2622-4771

https://jurnal.stie-aas.ac.id/index.php/IJEBAR

$\sigma^{2}=E\left[(X-\mu)^{2}\right]=\int_{-\infty}^{\infty}(x-\mu)^{2} f(x)$ if $\mathrm{X}$ is continous

The positive root variance, $\sigma$, is called the standard deviation $\mathrm{X}$.

But for the discrete, there is a quick way to calculate it, i.e.

$$
\begin{aligned}
\sigma^{2} & =\sum_{x}(x-\mu)^{2} f(x)=\sum_{x}\left(x^{2}-2 x \mu+\mu^{2}\right) f(x) \\
\sigma^{2} & =\sum_{x}\left(x^{2}\right) f(x)-2 \mu \sum_{x} x f(x)+\mu^{2} \sum_{x} f(x)
\end{aligned}
$$

Because $\mu=\sum_{x} x f(x)$ according to the theory of random or averaged variables,

and $\sum_{x} f(x)=1$ for discrete opportunity distribution, then

$\sigma^{2}=\sum_{x}\left(x^{2}\right) f(x)-\mu^{2}=E\left(X^{2}\right)-\mu^{2}$

[WAL95].

\section{Standard Deviation}

Standard Deviation $(\sigma)$, the root of variance, is a benchmark of variation in probability theory. Standard deviation shows how much variation from the average value. Standard deviation is the root of variance.

$\sum_{x}\left(x^{2}\right) f(x)-\mu^{2}$ 国

\section{Covariance}

Covariance measures how much the two variables change together, while variance is covariance which has two identical values.

$\operatorname{Cov}(\mathrm{X}, \mathrm{Y})=\mathrm{E}[(\mathrm{X}-\mathrm{E}[\mathrm{X}])(\mathrm{Y}-\mathrm{E}[\mathrm{Y}])]$, where $\mathrm{X}$ and $\mathrm{Y}$ are real numbers and $\mathrm{E}[\mathrm{X}]$ is the Expected Value of $\mathrm{X}$.

If $\mathrm{X}, \mathrm{Y}, \mathrm{W}$ and $\mathrm{W}$ are real and $\mathrm{a}, \mathrm{b}, \mathrm{c}$ and $\mathrm{d}$ are constants then

$\operatorname{Cov}(X, a)=0$, meaning $X$ and a are mutually independent

$\operatorname{Cov}(X, X)=\operatorname{Var}(X)$ because $X$ and $X$ are identical

$\operatorname{Cov}(a X, b Y)=a b \operatorname{Cov}(X, Y)$

$\operatorname{Cov}(X+a, Y+b)=\operatorname{Cov}(X, Y)$

$\operatorname{Cov}(a X+b Y, c W+d V)=a c \operatorname{Cov}(X, W)+\operatorname{adCov}(X, V)+b c \operatorname{Cov}(X, V)+b d \operatorname{Cov}(Y, V)$

\section{Normal Distribution}

The most important continuous opportunity distribution in all fields of statistics is the normal distribution. The graph is called a bell-shaped normal curve. A continuous random variable $\mathrm{X}$ whose bell-shaped distribution is called a normal random variable [WAL95].

The solid function of the random variable is normal $\mathrm{X}$, where the mean and variance are $n(x ; \mu, \sigma)=\frac{1}{\sqrt{2 \pi \sigma}} e^{-(1 / 2)[(x-\mu) / \sigma]^{2}},-\infty<x<\infty$, [2.4] where $\pi=3,14159 \ldots$ and $e=2,71828 \ldots$ 
International Journal of Economics, Business, and Accounting Research (IJEBAR)

Peer Reviewed - International Journal

Vol-5, Issue-1, 2021 (IJEBAR)

E-ISSN: 2614-1280 P-ISSN 2622-4771

https://jurnal.stie-aas.ac.id/index.php/IJEBAR

By knowing $\mu$ and $\sigma$, then all the normal curves are known. For example, if $\mu=5$ and $\sigma=10$, then the ordinate $n(x ; 5,10)$ can be calculated for various values of $\mathrm{x}$ and the curve can be drawn. $\mu$ shows the center of the curve and shows the standard deviation [WAL95].

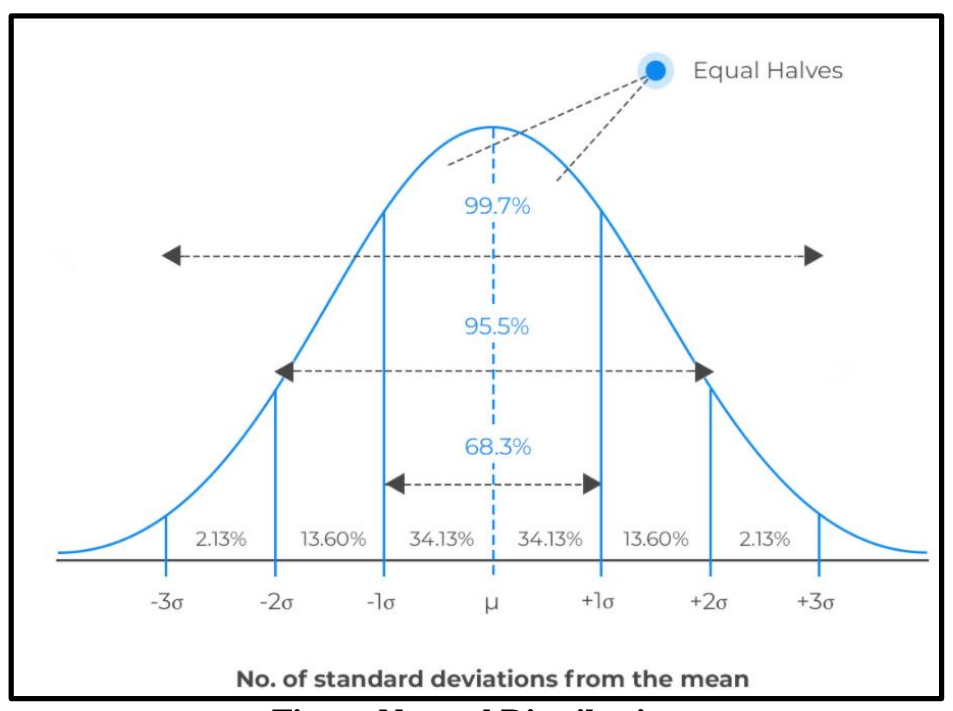

Figure Normal Distribution

It can be seen on the normal curve $n(x ; 5,10)$ shown in Figure II. 1 , which $\mu=5$ is the center point and $\sigma=10$ is the standard deviation.

There are five normal curve characteristics, namely:

1. Mode, the point on the flat axis that gives the maximum the curve is on $\sigma=10$

2. Curve as close to the upright axis as the average $\mu$

3. The curve has a turning point on $x=\mu \pm \sigma$, concave facing downward for $\mu-\sigma<x=\mu+\sigma$ and concave upward for the other value of $\mathrm{x}$.

4. Both ends of the normal curve approach the flat axis asymptote if the value of $\mathrm{x}$ moves away from $\mu$ in both left or right direction.

5. The entire area under the curve and above the flat axis is equal to 1 [WAL95].

\section{Relevant Financial Theories}

Rate of Return (ROR)

Rate of Return is the ratio of the profit or loss of an investment to the total amount of money invested.

$\mathrm{r} \quad=(\mathrm{Vf}-\mathrm{Vi}) / \mathrm{Vi}$

Where

$\mathrm{R} \quad=$ return

Vf $=$ Value of the final investment outcome

$\mathrm{Vi} \quad=$ initial investment value

In this final project, the return obtained from an increase or decrease in stock prices compared to the initial stock price.

\section{Compund Annual Growth Rate (CAGR)}


Compound Annual Growth Rate (CAGR) is a term in business and investment to uniform or equalize the annual profit of an investment over a certain period of time. CAGR is often used to compare the growth rates of two investments because CAGR offsets the effects of periodic return volatility which can make arithmetic meaning irrelevant. CAGR is often used to describe growth over a period of time from several business elements, for income or investment value. The CAGR calculation formula is like the formula below

$\operatorname{CAGR}\left(t_{0}, t_{n}\right)=\left(\frac{V\left(t_{n}\right)}{V\left(t_{0}\right)}\right)^{\frac{1}{t_{n}-t_{0}}}-1$

Where

$\mathrm{V}(\mathrm{t} 0)$ : initial value

$\mathrm{V}(\mathrm{tn})$ : final value

tn is the year at the end of the period

$\mathrm{t} 0$ is the year at the beginning of the period

tn $-\mathrm{t} 0$ : number of periods in a year,

\section{Markowitz Portfolio Theory \\ Basic concepts}

The basic concept of the Markowitz portfolio theory states that assets or stocks in an investment portfolio should not be chosen singly or alone, but should be combined with other stocks that have small or negative covariance, Thus the standard deviation of returns is smaller.

In the early 1960s, investors always discussed risk, but at a time when there were no specific measurement methods. The basis of the portfolio model was developed by Harry Markowitz which reduced the expected rate of return and for portfolio assets. Markowitz shows that the variance rate of return is an important measure for designing a portfolio. This formula of portfolio variance shows the importance of diversifying investments.

The Markowitz model has several assumptions about investor behavior, namely:

1. Investors consider each investment alternative as a probability of distribution of expected returns within a certain period

2. Investors maximize one expected utility period, and their utility curve points

3. It will reduce the marginal utility of wealth.

4. Investors make portfolio risk estimates based on expected return variability

5. Investors base their decisions solely on expected results and risks, so that their utility curve is a function of expected results and expected variance (or standard deviation) returns only.

6. For certain levels of risk, investors prefer a higher return than a lower return. Likewise, for the expected rate of return, investors prefer smaller risks

Based on this assumption, a single asset or asset portfolio is considered efficient if there are no other assets or portfolios that offer a higher expected return with lower or equal risk, or with a lower risk but the same expected return.

\section{Mathematical Model}

In the mathematical model, the following are definitions of return and volatility that will be used: 
International Journal of Economics, Business, and Accounting Research (IJEBAR)

Peer Reviewed - International Journal

Vol-5, Issue-1, 2021 (IJEBAR)

E-ISSN: 2614-1280 P-ISSN 2622-4771

https://jurnal.stie-aas.ac.id/index.php/IJEBAR

Returns from a portfolio are returns of a combination of assets based on the proportion of their weights.

Portfolio validity is a function of the correlation of the component assets.

Generally,

Expected Return

$E(R p)=\sum_{i} w i E(R i)$, where $\mathrm{Rp}$ is the return from the portfolio, $\mathrm{Ri}$ is the return of asset $\mathrm{i}$ and wi is the weighting of asset $i$.

Variety of Return Portolio

$\sigma_{p}^{2}=\sum_{i} w_{i}^{2} \sigma_{i}^{2}+\sum_{i} \sum_{j \neq i} w_{i} w_{j} \sigma_{i} \sigma_{j} \rho_{i j}$,

Where Pij is the correlation coefficient of the two assets

Portfolio volatility Return

$\sigma_{p}=\sqrt{\sigma_{p}^{2}}$

For a portfolio with two assets

Portfolio return

$\mathrm{E}\left(R_{p}\right)=w_{A} \mathrm{E}\left(R_{A}\right)+w_{B} \mathrm{E}\left(R_{B}\right)=w_{A} \mathrm{E}\left(R_{A}\right)+\left(1-w_{A}\right) \mathrm{E}\left(R_{B}\right)$.

Portfolio Variant

$\sigma_{p}^{2}=w_{A}^{2} \sigma_{A}^{2}+w_{B}^{2} \sigma_{B}^{2}+2 w_{A} w_{B} \sigma_{A} \sigma_{B} \rho_{A B}$

\section{Efficient Frontier on Markowitz Portfolio Management Theory}

Efficient Frontier describes the relationship between the return that can be expected from a portfolio and the magnitude of the risk (volatility) of the portfolio. This can be described as a curve in the risk graph against the expected return of the portfolio. Efficient Frontier provides the best return that can be expected for a certain level of risk or the lowest level of risk needed to achieve the expected level of return.

Efficient Frontier is a key concept in modern portfolio theory. What is quite interesting in post-modern portfolio theory is that there are a variety of Efficient Frontiers that can be adjusted according to the risk profile of investors.

The Efficient Frontier concept can be used to illustrate the benefits of investment diversification. An undiversified portfolio can be moved closer to Efficient Frontier by diversifying by combining it with other forms of investment that have little or even negative covariance. By diversifying, returns can be increased without the need to increase risk, or conversely reduce risk without reducing returns. 


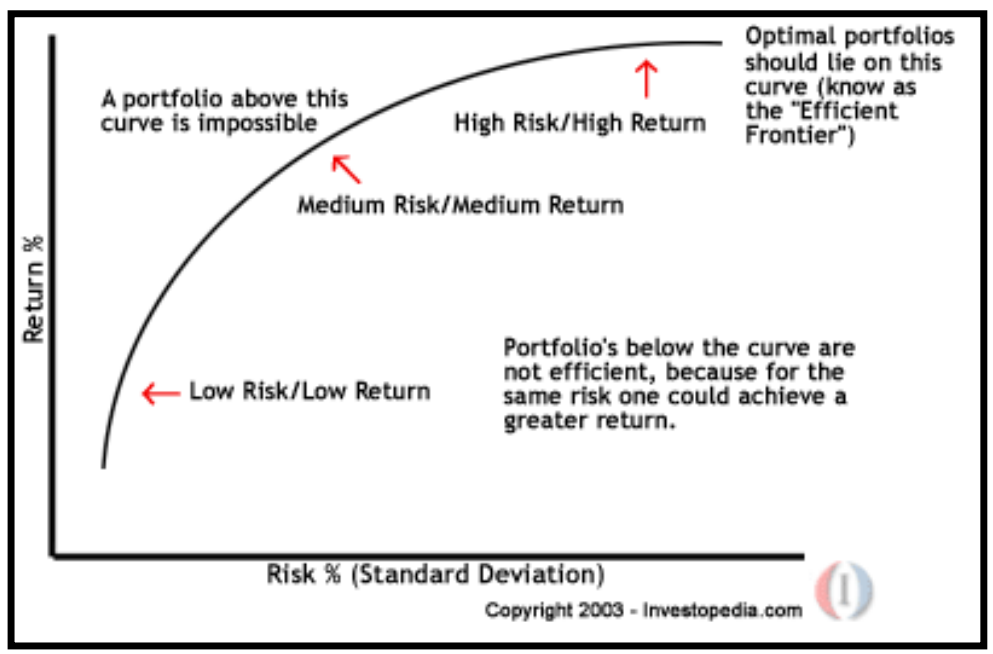

\section{Efficient Frontier Curve}

In figures above, there is a curved Efficient Frontier curve. The abscissa of the curve is the standard deviation of the return, and the ordinate is the average return. The area above the Efficient Frontier curve is the area where it is impossible to form a portfolio with a standard deviation and return on that number.

Whereas areas that are far below the Efficient Frontier curve are very inefficient portfolios because it is possible to form a portfolio that has the same return, but with a smaller risk profile. Portfolio formation that is right on the Efficient Frontier line is a form of portfolio that already has minimal risk, or optimal return or a combination of both that is very efficient.

\section{Research Method}

\section{A. Type Of Research}

This research is a descriptive study which is to find out whether the independent variables are one or more variables without making comparisons (Sulistiani, Topowijono, \& NP, 2017). This study aims to find out the symptoms and facts about the nature of a particular population or area. The approach used is a quantitative approach in the form of numbers or qualitative data created in the form of numbers. This study uses data in the form of a monthly closing stock price list of all companies incorporated in the Jakarta Islamic Index data, and the Indonesia overnight index average(Indonia) Rate in from January 2017 to December 2019. The data will be processed using a statistical formula that will find the results to be analyzed in order to obtain a conclusion.

\section{B. Data Population And Sample}

The data population in this study are all shares of the companies included in the JII index for the period 2009 to 2019, as many as 30 company shares. Because the list of JII shares from time to time always changes, all shares that have been included in the JII list in the past 10 years will be combined. From the list of joint companies will be seen whether they were active in stock trading in the past 1 year or not. Then we will compute the calculation based on the company's industrial sector.

\section{Source And Type Of Data}


International Journal of Economics, Business, and Accounting Research (IJEBAR)

Peer Reviewed - International Journal

Vol-5, Issue-1, 2021 (IJEBAR)

E-ISSN: 2614-1280 P-ISSN 2622-4771

https://jurnal.stie-aas.ac.id/index.php/IJEBAR

Data collected in the form of secondary data obtained from the official sites www.idx.co.id and www.finance.yahoo.com during the years 2009 - 2019 and from the Bank Indonesia website from 2017 to 2019. Secondary data is the source of research data obtained through intermediary media or indirectly in the form of books, notes, evidence that already exists, or archives both published and not publicly published. The data required is the closing price of shares every month, the BI Rate and the Composite Stock Price Index each month for the period 2009 to 2019.

The Method Of Analyzing And Processing Data

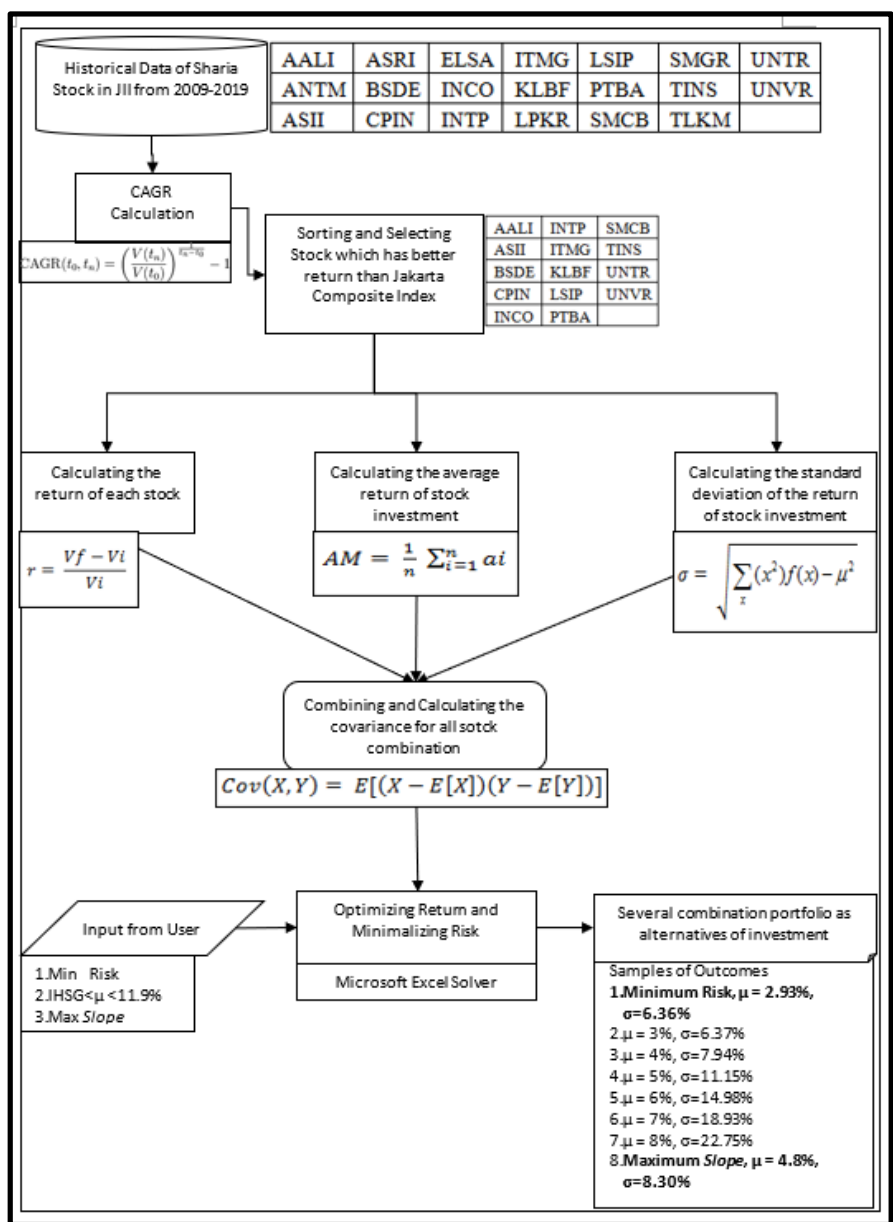


International Journal of Economics, Business, and Accounting Research (IJEBAR)

Peer Reviewed - International Journal

Vol-5, Issue-1, 2021 (IJEBAR)

E-ISSN: 2614-1280 P-ISSN 2622-4771

https://jurnal.stie-aas.ac.id/index.php/IJEBAR

The Markowitz portfolio management implementation process is divided into 9 steps, namely:

1. Prepare the JII historical stock price data for the past 10 years where the stock price has been adjusted whenever there is a distribution of dividends, stock splits and right issues

2. Calculate the CAGR of each share to determine the estimated return on investment per year

3. Sorting shares based on the CAGR and only taking stocks - stocks that have a higher return than IHSG returns

4. Calculate the monthly return of each share

5. Calculate the average monthly return of a stock investment

6. Calculate the standard deviation or standard deviation of monthly stock returns

7. Combine and calculate the covariance of stock returns

8. Optimizing returns and minimizing risk of stock investment according to various choices of users

9. Various alternative portfolio combinations with various returns and risk of stock investments.

\section{Analysis And Results}

Preparing, Calculating and Selecting the JII Stocks

In this research, the data used are the historical prices of 30 stocks included in the Jakarta Islamic Index from January 2009 to December 2019 where the stock price has been adjusted whenever there is a distribution of dividends, stock splits, and right issues. The data then are sorted based on its CAGR from the biggest to the lowest. The stocks that have CAGR greater than that of IHSG will be included in the portfolio selection. Of these 30 stocks, only 22 stocks can beat the return of IHSG index.

Furthermore, the monthly return, average monthly return, and the standard deviation of monthly return of these 22 stocks are also calculated to cater to the need of portfolio selection. Additionally, the covariances of these 22 Stocks are also calculated to determine which group of stocks is suitable to be included in the portfolio. 
International Journal of Economics, Business, and Accounting Research (IJEBAR)

Peer Reviewed - International Journal

Vol-5, Issue-1, 2021 (IJEBAR)

E-ISSN: 2614-1280 P-ISSN 2622-4771

https://jurnal.stie-aas.ac.id/index.php/IJEBAR

\begin{tabular}{|c|c|c|c|c|c|c|c|c|c|c|}
\hline Stock & $\begin{array}{l}\text { Start } \\
\text { Date }\end{array}$ & te & M & \begin{tabular}{|l|} 
Avg mo \\
Return \\
\end{tabular} & \begin{tabular}{|c|} 
SD \\
Return
\end{tabular} & S & $E_{1}$ & \begin{tabular}{|c|} 
Total \\
Return \\
\end{tabular} & CAGR & $>10 \mathrm{y}$ \\
\hline BTPS.JK & $5 / 1 / 2018$ & $7 / 1 / 2020$ & 27 & $4.13 \%$ & $13.13 \%$ & $1,545.98$ & $3,450.00$ & $123 \%$ & $42.87 \%$ & $\mathrm{~N}$ \\
\hline \begin{tabular}{|l|} 
MDKA.JK \\
\end{tabular} & $6 / 1 / 2015$ & $7 / 1 / 2020$ & 62 & $03 \%$ & \begin{tabular}{|l|}
$10.06 \%$ \\
\end{tabular} & 383.67 & ,790.00 & $367 \%$ & $34.73 \%$ & $\mathrm{~N}$ \\
\hline TPIA.JK & $9 / 1 / 2010$ & $7 / 1 / 2020$ & 119 & $66 \%$ & $16.63 \%$ & 4.51 & 325.00 & $7711 \%$ & $33.92 \%$ & $\mathrm{Y}$ \\
\hline ACES.JK & 9/1/2010 & $7 / 1 / 2020$ & 119 & $70 \%$ & \begin{tabular}{|l|l|}
$10.57 \%$ \\
\end{tabular} & 137.98 & $1,750.00$ & $1168 \%$ & $29.20 \%$ & $\mathrm{Y}$ \\
\hline BRPT.JK & $9 / 1 / 2010$ & $7 / 1 / 2020$ & 119 & $3.23 \%$ & $19.33 \%$ & 123.78 & 950.00 & $668 \%$ & $22.82 \%$ & $\mathrm{Y}$ \\
\hline UNVR.JK & $9 / 1 / 2010$ & $7 / 1 / 2020$ & 119 & $1.76 \%$ & $7.23 \%$ & $1,423.56$ & $8,290.72$ & $482 \%$ & $19.44 \%$ & $\mathrm{Y}$ \\
\hline ICBP.JK & $9 / 1 / 2010$ & $7 / 1 / 2020$ & 119 & $1.99 \%$ & \begin{tabular}{|l|}
$12.73 \%$ \\
\end{tabular} & $1,951.69$ & $8,989.57$ & $361 \%$ & $16.65 \%$ & $\mathrm{Y}$ \\
\hline KLBF.JK & 9/1/2010 & $7 / 1 / 2020$ & 119 & $1.56 \%$ & $7.66 \%$ & 351.24 & $1,565.00$ & $346 \%$ & $16.26 \%$ & $\mathrm{Y}$ \\
\hline CPIN.JK & 9/1/2010 & $7 / 1 / 2020$ & 119 & $1.96 \%$ & $12.35 \%$ & $1,481.79$ & 3.01 & $315 \%$ & $15.42 \%$ & $\mathrm{Y}$ \\
\hline SCMA.JK & 9/1/2010 & $7 / 1 / 2020$ & 119 & $7.57 \%$ & $72.54 \%$ & 313.93 & 5.00 & $309 \%$ & $15.27 \%$ & $\mathrm{Y}$ \\
\hline TLKM.JK & $9 / 1 / 2010$ & $7 / 1 / 2020$ & 119 & $1.44 \%$ & $7.71 \%$ & 7.36 & 0.00 & $292 \%$ & $14.78 \%$ & $\mathrm{Y}$ \\
\hline AKRA.JK & $9 / 1 / 2010$ & $7 / 1 / 2020$ & 119 & $48 \%$ & $11.10 \%$ & 998.77 & 57 & $183 \%$ & $11.07 \%$ & $\mathrm{Y}$ \\
\hline JPFA.JK & $9 / 1 / 2010$ & $7 / 1 / 2020$ & 119 & $1.90 \%$ & \begin{tabular}{|l|l|}
$14.72 \%$ \\
\end{tabular} & 386.57 & 0.00 & $174 \%$ & $10.71 \%$ & $\mathrm{Y}$ \\
\hline PTBA.JK & $9 / 1 / 2010$ & $7 / 1 / 2020$ & 119 & $4.27 \%$ & \begin{tabular}{|l|l|}
$38.72 \%$ \\
\end{tabular} & 762.59 & $2,030.00$ & $166 \%$ & $10.38 \%$ & $\mathrm{Y}$ \\
\hline \begin{tabular}{|l|} 
MNCN.JK \\
\end{tabular} & $9 / 1 / 2010$ & $7 / 1 / 2020$ & 119 & $1.75 \%$ & \begin{tabular}{|l|l|}
$14.72 \%$ \\
\end{tabular} & 348.09 & 820.00 & $136 \%$ & $9.02 \%$ & $\mathrm{Y}$ \\
\hline WIKA.JK & $9 / 1 / 2010$ & $7 / 1 / 2020$ & 119 & $63 \%$ & $13.08 \%$ & 512.96 & $1,190.00$ & $132 \%$ & $86 \%$ & $\mathrm{Y}$ \\
\hline ASIIJJK & 9/1/2010 & $7 / 1 / 2020$ & 119 & $1.00 \%$ & $8.55 \%$ & $2,427.42$ & $5,150.00$ & $112 \%$ & $88 \%$ & $\mathrm{Y}$ \\
\hline CTRA.JK & 9/1/2010 & $7 / 1 / 2020$ & 119 & $1.47 \%$ & \begin{tabular}{|l|}
$12.97 \%$ \\
\end{tabular} & 331.62 & 646.75 & $95 \%$ & $6.97 \%$ & $Y$ \\
\hline ERAA.JK & $12 / 1 / 2011$ & $7 / 1 / 2020$ & 104 & $2.24 \%$ & \begin{tabular}{|l|}
$18.70 \%$ \\
\end{tabular} & 821.41 & $1,470.00$ & $79 \%$ & $6.95 \%$ & $\mathrm{~N}$ \\
\hline PWON.JK & 9/1/2010 & $7 / 1 / 2020$ & 119 & $13 \%$ & \begin{tabular}{|l|l|}
$10.69 \%$ \\
\end{tabular} & 223.35 & 424.00 & $90 \%$ & $6.68 \%$ & $\mathrm{Y}$ \\
\hline UNTR.JK & $9 / 1 / 2010$ & $7 / 1 / 2020$ & 119 & $0.75 \%$ & $8.61 \%$ & $13,636.79$ & $21,350.00$ & $57 \%$ & $62 \%$ & $Y$ \\
\hline INDFJJK & $9 / 1 / 2010$ & $7 / 1 / 2020$ & 119 & $0.61 \%$ & $7.04 \%$ & $4,051.90$ & $6,183.37$ & $53 \%$ & $35 \%$ & $Y$ \\
\hline JKSE & $9 / 1 / 2010$ & $7 / 1 / 2020$ & 119 & $0.41 \%$ & $4.01 \%$ & $3,501.19$ & $5,149.63$ & $47 \%$ & $3.97 \%$ & $\mathrm{Y}$ \\
\hline ISMR.JK & $9 / 1 / 2010$ & $7 / 1 / 2020$ & 119 & $0.71 \%$ & $8.72 \%$ & $2,758.97$ & $3,930.00$ & $42 \%$ & $3.63 \%$ & $\mathrm{Y}$ \\
\hline SMGR.JK & 9/1/2010 & $7 / 1 / 2020$ & 119 & $0.57 \%$ & $9.25 \%$ & $7,777.35$ & $9,225.00$ & $19 \%$ & $1.74 \%$ & $\mathrm{Y}$ \\
\hline INTP.JK & $9 / 1 / 2010$ & $7 / 1 / 2020$ & 119 & $0.34 \%$ & $9.21 \%$ & $13,158.27$ & $11,873.99$ & $-10 \%$ & $-1.03 \%$ & $\mathrm{Y}$ \\
\hline INCO.JK & 9/1/2010 & $7 / 1 / 2020$ & 119 & $0.90 \%$ & $14.68 \%$ & $4,065.21$ & $3,420.00$ & $-16 \%$ & $-1.73 \%$ & $\mathrm{Y}$ \\
\hline ADRO.JK & $9 / 1 / 2010$ & $7 / 1 / 2020$ & 119 & $0.48 \%$ & \begin{tabular}{|l|}
$11.39 \%$ \\
\end{tabular} & $1,310.89$ & $1,085.00$ & $-17 \%$ & $-1.89 \%$ & $\mathrm{Y}$ \\
\hline JKII & $3 / 1 / 2013$ & $7 / 1 / 2020$ & 89 & $-0.10 \%$ & $4.35 \%$ & 660.34 & 555.63 & $-16 \%$ & $-2.30 \%$ & $\mathrm{~N}$ \\
\hline EXCL.JK & $9 / 1 / 2010$ & $7 / 1 / 2020$ & 119 & $-0.06 \%$ & $9.95 \%$ & $4,853.10$ & $2,500.00$ & $-48 \%$ & $-6.47 \%$ & $\mathrm{Y}$ \\
\hline PGAS.JK & 9/1/2010 & $7 / 1 / 2020$ & 119 & $0.15 \%$ & $12.45 \%$ & $2,634.83$ & $1,265.00$ & $-52 \%$ & $-7.13 \%$ & $\mathrm{Y}$ \\
\hline ANTM.JK & $9 / 1 / 2010$ & $7 / 1 / 2020$ & 119 & $0.20 \%$ & \begin{tabular}{|l|}
$13.65 \%$ \\
\end{tabular} & $1,639.22$ & 730.00 & $-55 \%$ & \begin{tabular}{|l|}
$-7.83 \%$ \\
\end{tabular} & Y \\
\hline
\end{tabular}

All of the 22 Stocks which have greater average monthly return than IHSG have higher risk than IHSG. To reduce the risk and to maintain the higher return, we need to calculate the covariance of all these pairs of 22 stocks. If the covariance is very small or even has a negative value, then the chance to reduce the risk is likely to be achieved. In the table below, we can see the whole calculation of the 22 stocks.

As we can see from the table above, some stock such as UNVR, ICBP, CPIN and PTBA have several negative values of covariance. Therefore, we have the luxury to form a portfolio that has a higher return than IHSG and has lower risk than IHSG.

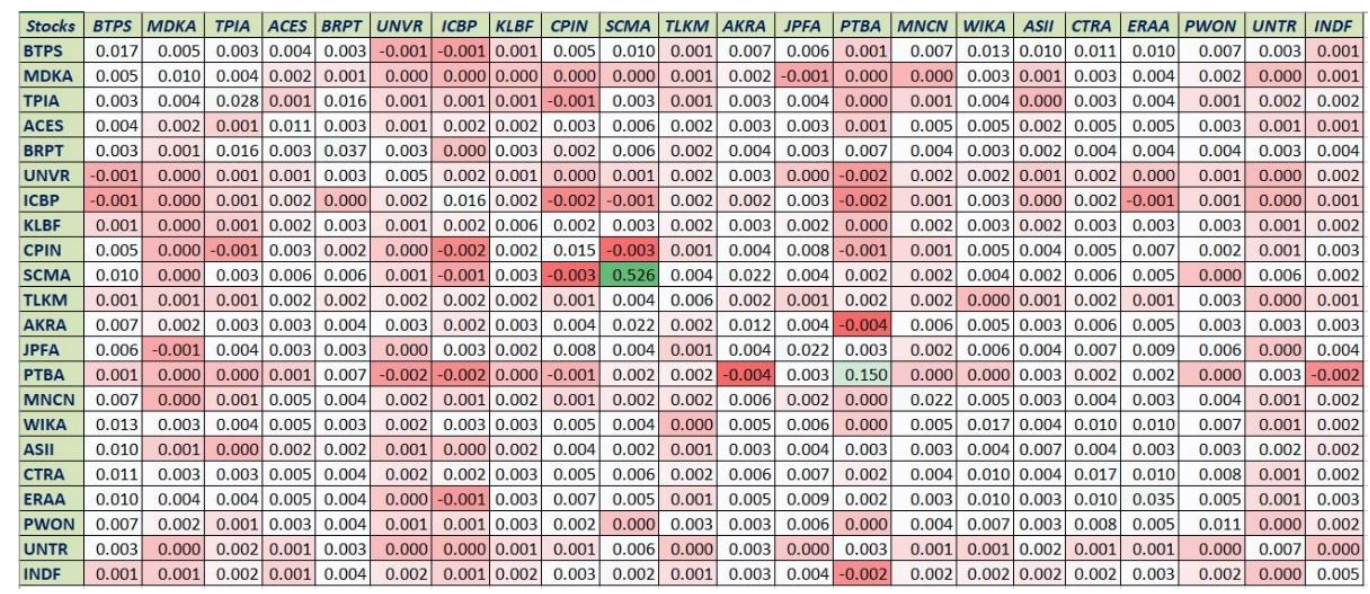

Optimizing Returns and Minimizing the Risk of Portfolio 
International Journal of Economics, Business, and Accounting Research (IJEBAR)

Peer Reviewed - International Journal

Vol-5, Issue-1, 2021 (IJEBAR)

E-ISSN: 2614-1280 P-ISSN 2622-4771

https://jurnal.stie-aas.ac.id/index.php/IJEBAR

By using the solver from Microsoft Excel, we can find a portfolio arrangement with minimal risk from the combination of the fourteen stocks above. If the result we want to get is a very low-risk portfolio.

In the Microsoft Excel solver, we select cell D33 (slope of return) as the target cell, then in the equal to section, we select Max so that the results obtained are maximal. We also put E5 E26 as the changing variable cells, so that Microsoft excel's solver will find the maximum value of cell D33 by changing the aforementioned variable cells.

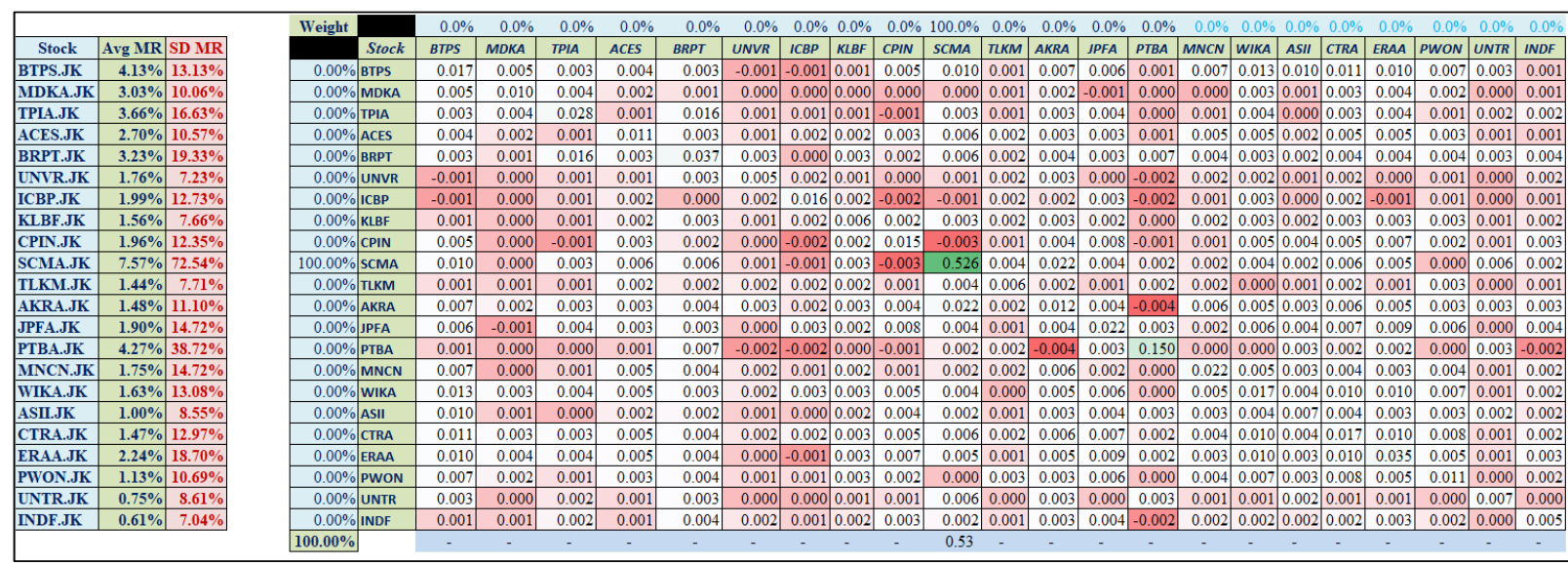

The result of Microsoft Excel's solver calculation is the maximum value of the slope is 0.59 that has a combined average return $2.7 \%$ per month and combined standard deviation of return $5.1 \%$.

Besides maximizing the slope in the cell D33, we also put D32 (standard deviation of return) as the objective and select Min in the equal to section, so that the value of the standard deviation of return will be minimized. The result of Microsoft Excel's solver calculation is the minimum value of the standard deviation is $4.09 \%$ with the combined average return $1.59 \%$ per month. 
International Journal of Economics, Business, and Accounting Research (IJEBAR)

Peer Reviewed - International Journal

Vol-5, Issue-1, 2021 (IJEBAR)

E-ISSN: 2614-1280 P-ISSN 2622-4771

https://jurnal.stie-aas.ac.id/index.php/IJEBAR

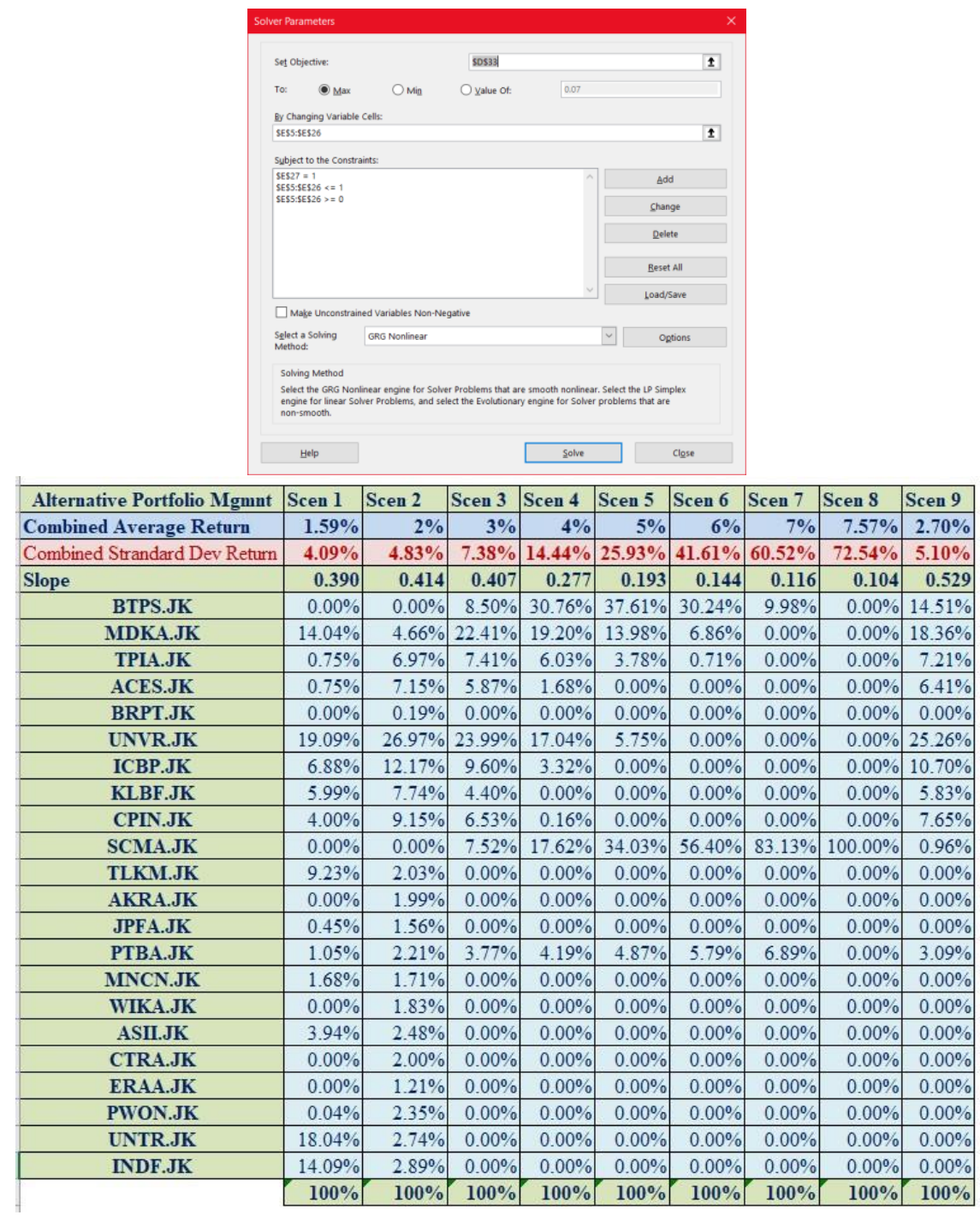

Based on these two calculations, we then know that the average return will range from $1.59 \%$ per month to $7.57 \%$ per month if we put all of the money in the SCMA stock. Thus, we use Microsoft Excel's solver to calculate all the rounded average returns from $2 \%$ to $7 \%$. The calculation results are shown in the above table, with 9 scenarios of portfolio arrangements.

As we can see, two scenarios have a competitive edge. The first one is the safest portfolio shown in scenario 1 since the combined standard deviation of return can be reduced to $4.09 \%$. The second one is the optimized portfolio selection shown in scenario 9 which has maximum slope of the return at 0.529 with the average return at $2.7 \%$ per month and the standard deviation of return at $5.1 \%$.

\section{Business Solution Implementation}

These two scenarios can not be implemented directly in the real stock market easily since we have a constraint in the size of lot in Indonesian stock market. In the Indonesian stock market, 
International Journal of Economics, Business, and Accounting Research (IJEBAR)

Peer Reviewed - International Journal

Vol-5, Issue-1, 2021 (IJEBAR)

E-ISSN: 2614-1280 P-ISSN 2622-4771

https://jurnal.stie-aas.ac.id/index.php/IJEBAR

the smallest size of stock purchase in the regular market is 100 stocks. Therefore we have to calculate what is the smallest amount of money we have to invest in each of these scenarios.

In scenario 1, we have to invest at least Rp 100,627,607. The calculation is shown in the below table.

\begin{tabular}{|l|r|r|r|r|r|}
\hline \multicolumn{3}{|c|}{ Minimum Investment } & \multicolumn{2}{|c|}{ Rp } & \multicolumn{1}{c|}{$\mathbf{1 0 0 , 6 2 7 , 6 0 7}$} \\
\hline \multicolumn{2}{|c|}{ average monthly return } & $: 1.59 \%$, stdev return $: 4.09 \%$ \\
\hline Stock & $\begin{array}{c}\text { Composition } \\
\text { scen 1 }\end{array}$ & $\begin{array}{c}\text { lot } \\
\text { size }\end{array}$ & $\begin{array}{c}\text { Stock } \\
\text { Price }\end{array}$ & $\begin{array}{c}\text { Price } \\
\text { per lot }\end{array}$ & $\begin{array}{c}\text { minimal total } \\
\text { investasi }\end{array}$ \\
\hline BTPS & $0.00 \%$ & 100 & 3,450 & 345,000 & - \\
\hline MDKA & $14.04 \%$ & 100 & 1,790 & 179,000 & $1,274,598$ \\
\hline TPIA & $0.75 \%$ & 100 & 7,325 & 732,500 & $98,052,329$ \\
\hline ACES & $0.75 \%$ & 100 & 1,750 & 175,000 & $23,305,476$ \\
\hline BRPT & $0.00 \%$ & 100 & 950 & 95,000 & - \\
\hline UNVR & $19.09 \%$ & 100 & 8,291 & 829,072 & $4,343,986$ \\
\hline ICBP & $6.88 \%$ & 100 & 8,990 & 898,957 & $13,074,867$ \\
\hline KLBF & $5.99 \%$ & 100 & 1,565 & 156,500 & $2,613,454$ \\
\hline CPIN & $4.00 \%$ & 100 & 6,143 & 614,301 & $15,360,218$ \\
\hline SCMA & $0.00 \%$ & 100 & 1,285 & 128,500 & - \\
\hline TLKM & $9.23 \%$ & 100 & 3,050 & 305,000 & $3,305,669$ \\
\hline AKRA & $0.00 \%$ & 100 & 2,829 & 282,857 & - \\
\hline JPFA & $0.45 \%$ & 100 & 1,060 & 106,000 & $23,459,334$ \\
\hline PTBA & $1.05 \%$ & 100 & 2,030 & 203,000 & $19,369,368$ \\
\hline MNCN & $1.68 \%$ & 100 & 820 & 82,000 & $4,891,324$ \\
\hline WIKA & $0.00 \%$ & 100 & 1,190 & 119,000 & - \\
\hline ASII & $3.94 \%$ & 100 & 5,150 & 515,000 & $13,086,417$ \\
\hline CTRA & $0.00 \%$ & 100 & 647 & 64,675 & - \\
\hline ERAA & $0.00 \%$ & 100 & 1,470 & 147,000 & - \\
\hline PWON & $0.04 \%$ & 100 & 424 & 42,400 & $100,627,607$ \\
\hline UNTR & $18.04 \%$ & 100 & 21,350 & $2,135,000$ & $11,835,265$ \\
\hline INDF & $14.09 \%$ & 100 & 6,183 & 618,337 & $4,388,430$ \\
\hline
\end{tabular}

While in scenario *, we only have to invest at least $\mathrm{Rp} 13,334,131$. The calculation is shown in the below table.

\begin{tabular}{|c|c|c|c|c|c|}
\hline \multicolumn{3}{|c|}{ Minimum Investment } & \multirow{2}{*}{\multicolumn{3}{|c|}{$\begin{array}{cc}\mathbf{R p} & \mathbf{1 3 , 3 4 4 , 1 3 1} \\
n: 2.7 \%, \text { stdev return }: 5.1 \%\end{array}$}} \\
\hline \multicolumn{3}{|c|}{ average monthly return $: 2.7 \%$, stdev return $: 5.1 \%$} & & & \\
\hline Stock & $\begin{array}{c}\text { Composition } \\
\text { scen } 9\end{array}$ & $\begin{array}{l}\text { lot } \\
\text { size }\end{array}$ & $\begin{array}{l}\text { Stock } \\
\text { Price }\end{array}$ & $\begin{array}{l}\text { Price } \\
\text { per lot }\end{array}$ & $\begin{array}{l}\text { minimal total } \\
\text { investasi }\end{array}$ \\
\hline BTPS & $14.51 \%$ & 100 & 3,450 & 345,000 & $2,377,851$ \\
\hline MDKA & $18.36 \%$ & 100 & 1,790 & 179,000 & 974,836 \\
\hline TPIA & $7.21 \%$ & 100 & 7,325 & 732,500 & $10,157,091$ \\
\hline ACES & $6.41 \%$ & 100 & 1,750 & 175,000 & $2,728,451$ \\
\hline BRPT & $0.00 \%$ & 100 & 950 & 95,000 & - \\
\hline UNVR & $25.26 \%$ & 100 & 8,291 & 829,072 & $3,281,562$ \\
\hline ICBP & $10.70 \%$ & 100 & 8,990 & 898,957 & $8,402,680$ \\
\hline KLBF & $5.83 \%$ & 100 & 1,565 & 156,500 & $2,682,761$ \\
\hline CPIN & $7.65 \%$ & 100 & 6,143 & 614,301 & $8,026,877$ \\
\hline SCMA & $0.96 \%$ & 100 & 1,285 & 128,500 & $13,344,131$ \\
\hline TLKM & $0.00 \%$ & 100 & 3,050 & 305,000 & - \\
\hline AKRA & $0.00 \%$ & 100 & 2,829 & 282,857 & - \\
\hline JPFA & $0.00 \%$ & 100 & 1,060 & 106,000 & - \\
\hline PTBA & $3.09 \%$ & 100 & 2,030 & 203,000 & $6,567,804$ \\
\hline MNCN & $0.00 \%$ & 100 & 820 & 82,000 & - \\
\hline WIKA & $0.00 \%$ & 100 & 1,190 & 119,000 & - \\
\hline ASII & $0.00 \%$ & 100 & 5,150 & 515,000 & - \\
\hline CTRA & $0.00 \%$ & 100 & 647 & 64,675 & - \\
\hline ERAA & $0.00 \%$ & 100 & 1,470 & 147,000 & - \\
\hline PWON & $0.00 \%$ & 100 & 424 & 42,400 & - \\
\hline UNTR & $0.00 \%$ & 100 & 21,350 & $2,135,000$ & - \\
\hline INDF & $0.00 \%$ & 100 & 6,183 & 618,337 & - \\
\hline
\end{tabular}


International Journal of Economics, Business, and Accounting Research (IJEBAR)

Peer Reviewed - International Journal

Vol-5, Issue-1, 2021 (IJEBAR)

E-ISSN: 2614-1280 P-ISSN 2622-4771

https://jurnal.stie-aas.ac.id/index.php/IJEBAR

\section{Closing}

\section{Conclusion}

From 30 Stocks that are included in Jakarta Islamic Index, only 22 Stocks have better CAGR than that of IHSG Index. Additionally, by calculating the covariance of the aforementioned Stocks, we will have pairs of stocks that have negative covariance, and therefore can reduce the standard deviation of return and thus reduce the risk in investing.

By using Microsoft Excel's solver we can obtain several portfolio arrangements, and then choose two scenarios that have competitive edge. First, the one with the smallest standard deviation of return as shown in scenario 1 . Second, the one with the maximum slope of return as shown in scenario 9.

\section{References}

Astra AgroLestari, Annual Report 2011, www.astra-agro.co.id , 2011

Astra International, Annual Report 2011, www.astra.co.id , 2011

Bisnis Indonesia, Harga Komoditas Biang Keladi Target Inflasi Meleset http://www.bisnis.com/ekonomi/makro/25307-harga-komoditas-biang-keladi-targetinflasi-meleset ,2011

BUMN, Kementrian, Lonjakan Harga Pangan Picu Inflasi http://www.bumn.go.id/ptpn5/id/publikasi/berita/lonjakan-harga-pangan-picu-inflasiimplementasi-acfta-beri-efek-deflasi-pada-tahun-ini/ ,2011

Bumi Serpong Damai, Annual Report 2011, www.bsdcity.com , 2011

Chart Nexus, Chart of Indonesian Stocks, www.chartnexus.com, version 3.2.3. , 2011

Charoen Pokphand Indonesia, Annual Report 2011, www.cp.co.id , 2011

Economist, at Large, Introduction to Portfolio Theory, http://economistatlarge.com/leadstory/introduction-to-portfolio-theory , 2011

International Nickel, Annual Report 2011, www.pt-inco.co.id , 2011

Indocement Tunggal Perkasa, Annual Report 2011, www.indocement.co.id , 2011

Investopedia, Efficient Frontier, www.investopedia.com, 2011

Indo Tambangraya Megah, Annual Report 2011, www.itmg.co.id , 2011

Kalbe Farma, Annual Report 2011, www.kalbe.co.id , 2011

London Sumatra Plantation, Annual Report 2011, www.londonsumatra.com, 2011

Bukit Asam, Annual Report 2011, www.ptba.co.id, 2011

Reily, Frank and Keith Brown, Invesment Abalysis and Portfolio Management, South- Western College Pub, 2002

Holcim Indonesia , Annual Report 2011, www.holcim.co.id , 2011

Timah, Annual Report 2011, www.timah.com , 2011

United Tractor, Annual Report 2011, www.unitedtractors.com ,2011

Unilever Indonesia, Annual Report 2011, www.unilever.co.id , 2011

Walpole, Ronald E dan Raymondm H Myers, Ilmu Peluang dan Statistik Untuk Insinyur dan Ilmuwan, Edisi ke-4, Penerbit ITB, 1995 